\title{
Characterization of Phenolic Constituents and Pharmacological Activity of Achillea vermicularis
}

\author{
T. TAKIN* I. BALKAN, D. TANKIN AND A. DOGN
}

Department of Pharmacognosy, Faculty of Pharmacy, Marmara University, ${ }^{1}$ Department of Pharmacognosy, Faculty of Pharmacy, University of Health Sciences, ${ }^{2}$ Department of Analytical Chemistry, Faculty of Pharmacy, Istanbul Yeni Yüzyıl University, ${ }^{3}$ Department of Pharmaceutical Botany, Faculty of Pharmacy, Marmara University, Istanbul, Turkey

\section{Taskin et al.: Biological activity of Achillea vermicularis}

\begin{abstract}
The aim of the present study was to compare for the first time, the antiinflammatory, antioxidant and antiurease activities of 15 different extracts of Achillea vermicularis, which were obtained from three extraction methods using five different solvents. Phenolic contents in chloroform extract showed strong antiinflammatory and antioxidant activity and were analysed by high-performance liquid chromatography with diode-array detection and confirmed by liquid chromatography quadrupole time-of-flight mass spectrometry. The active phenolic compounds in chloroform extracts were identified as chlorogenic acid, caffeic acid, rutin, dicaffeoylquinic acid, naringenin, quercetagetin 3,6-dimethyl ether, and 8-hydroxysalvigenin. All these compounds except caffeic acid were detected for the first time in Achillea vermicularis. These results indicated that chloroform extract of the plant possessed a high potential to be used as a natural source in food and pharmaceutical industry.
\end{abstract}

Key words: Achillea vermicularis Trin., antioxidant, antiurease, antiinflammatory, HPLC-DAD-MS

The genus Achillea L. belongs to Asteraceae (Compositae) family contains more than 100 species. These species have hairy and aromatic leaves and occurs in Europe and temperate areas of Asia and a few grow in North America ${ }^{[1]}$. Many species of this genus has been commonly used in folk medicine for the treatment of fever, cough, bronchitis, asthma, skin inflammation, stomach ailment, gastritis, and bladder stones and liver ailments ${ }^{[2]}$. The aerial parts of different species of Achillea have been used widely in folk medicine for the preparation of remedies with antiinflammatory spasmolytic, haemostatic, digestive, antiphlogostic, and cholagogue effects ${ }^{[3]}$. The genus Achillea comprises flavoured species, which produce intense essential oils contain monoterpenes and sesquiterpenes compounds. These essential oils exhibit antibacterial, antifungal, and antioxidant properties ${ }^{[1,3,4]}$. It has been reported that extracts of Achillea sp. exhibited antimicrobial, antihypertensive, antihyperlipidemic, antispasmodic, antidiabetic, antispermatogenic, antifertility, and immunosuppressive activities ${ }^{[5]}$. The chemistry of the members of this family has been extensively studied and up to now more than 28 compounds have been identified ${ }^{[3]}$. Achillea sp. were reported to contain essential oils, sesquiterpenes,

terpenoids, lignans, amino acid derivatives, fatty acids, alkamides ( $p$-hydoxyphenethylamide IV) and phenolic compounds like flavonoids and phenolic acids ${ }^{[1,6]}$.

Achillea sp. is one of the most valuable and economical plants of Anatolia. Herbal teas prepared from aerial parts of different Achillea sp. have traditionally been used for antiphlogostic, spasmolytic, and as an antiinflammatory agent for the treatment of rheumatic pain. Achillea vermicularis Trin. is a member of the genus Achillea L. and its flowers have been used in the treatment of diarrhoea and against kidney pains. In addition, the capitulum of the plant is used in the treatment of asthma ${ }^{[7,8]}$. The main constituents of essential oil from plant aerial parts were analysed as 1,8-cineole, camphor, borneol, piperitone and camphor ${ }^{[9,10]}$.

Helicobacter pylori causes chronic inflammation in stomach and duodenum and is the common cause of

This is an open access article distributed under the terms of the Creative Commons Attribution-NonCommercial-ShareAlike 3.0 License, which allows others to remix, tweak, and build upon the work non-commercially, as long as the author is credited and the new creations are licensed under the identical terms

Accepted 10 February 2019

Revised 17 September 2018

Received 02 April 2018

Indian J Pharm Sci 2019;81(2):293-301 
gastric and duodenal ulcers worldwide. This bacterium releases urease that converts urea into ammonia. This enzyme produces an alkaline environment that makes it suitable for bacterial growth and manifestation of the disease ${ }^{[11]}$. For the past $20 \mathrm{y}$, the recommended first line therapy for $H$. pylori eradication consisted of a combination of a proton pump inhibitor, omeprazole, and antibiotics including amoxicillin and clarithromycin. However, the increased $H$. pylori resistance for these antibiotics (especially clarithromycin) has made this treatment an unattractive option in recent years ${ }^{[12]}$.

More recently, numerous studies have been carried out on antiurease activity of plant extracts, partially purified fractions, and natural compounds ${ }^{[13]}$. Herbal teas prepared from some Achillea species have been traditionally used for abdominal pain and flatulence in Turkey ${ }^{[1]}$. Therefore, in this study, antiurease activities of different extracts from $A$. vermicularis were investigated for the first time.

A great deal of attention has been given to the involvement of free radicals in chronic disease processes. Oxidative stress is an imbalance between reactive oxygen species levels and low antioxidant mechanism activity. The oxidative stress plays an important role in inflammation diseases ${ }^{[14]}$. Inflammation is the first response of the body to an infection or injury. Researching natural compounds that interfere with these mechanisms by preventing long-term inflammation can be beneficial to human health ${ }^{[15]}$. Epidemiological research has revealed a negative relationship between natural products and chronic diseases (chronic inflammation, cancer). These physiological functions of natural products could partly be attributed to the abundance of phenolic compounds. These phenolic compounds have significant biological activity such as antioxidant, antiinflammatory, antimicrobial, anticarcinogenic ${ }^{[15-17]}$.

Therefore, the present study was aimed at obtaining 15 different extracts from $A$. vermicularis using maceration, Soxhlet and ultrasonic extraction methods to examine their antioxidant and antiurease activities, and to evaluate their antiinflammatory activities in vitro. The phenolic compound composition in the chloroform extracts using maceration was analysed using high-performance liquid chromatography with diode-array detection (HPLC-DAD) and confirmed by liquid chromatography tandem mass spectrometry (LC-MS/MS).

\section{MATERIALS AND METHODS}

Aerial parts of Achillea vermicularis Trin. were collected from Elazığ, Turkey in June and during flowering period. The species was authenticated and a voucher specimen (MARE-18071) was deposited at the Marmara University Pharmacy herbarium for future reference. The dried parts of the plant were powdered using a mechanic grinder (Renas, RBT1250). Three different extraction methods were followed to prepare crude extracts from this plant aerial part.

\section{Preparation of plant extracts:}

About $80 \mathrm{~g}$ of plant powder was extracted by maceration using $1000 \mathrm{ml}$ each of $n$-hexane $(\mathrm{MH})$, chloroform (MC), ethyl acetate (MEA), ethanol (ME) and 50:50, v/v ethanol-water (MEW) for $120 \mathrm{~h}$ at $25^{\circ}$. Plant powder $(80 \mathrm{~g})$ was extracted in a Soxhlet apparatus using $300 \mathrm{ml}$ each of $n$-hexane (SH), chloroform (SC), ethyl acetate (SEA), ethanol (SE) and $50: 50, \quad v / v$ ethanol-water (SEW). Plant powder $(80 \mathrm{~g})$ was extracted by sonication with $300 \mathrm{ml}$ each of $n$-hexane (UH), chloroform (UC), ethyl acetate (UEA), ethanol (UE) and 50:50, $v / v$ ethanol-water (UEW) for $30 \mathrm{~min}$. in ultrasonic bath $(60 \mathrm{~Hz})$ set at $30^{\circ}$. These fifteen different extracts of $A$. vermicularis were concentrated using a rotary evaporator.

\section{Yield of total phenolic contents:}

The extraction yield was calculated to determine the effectiveness of the solvent on phenolic compounds in plant extracts. The total phenolic contents of the extracts prepared using three different extraction methods were determined using the Folin-Ciocalteu reagent (FCR) method and the results obtained were expressed as $\mathrm{mg}$ gallic acid equivalents/mg extract $(\mathrm{GAE} / \mathrm{mg})^{[18]}$.

\section{In vitro evaluation of antioxidant activity:}

The ability of free radical scavenging of the 15 extracts was determined using the 2,2-diphenyl-1picrylhydrazyl (DPPH) method and the results of the experiment were expressed as $\mathrm{IC}_{50}(\mathrm{mg} / \mathrm{ml})^{[19]}$. The 2,2'-azino-bis(3-ethylbenzothiazoline-6-sulphonic acid) $\left(\mathrm{ABTS}^{\cdot+}\right)$ scavenging properties of 15 extracts was calculated as Trolox equivalent and the data obtained was presented as $\mathrm{mM}$ Trolox/mg extract ${ }^{[20]}$. The ability of ferric reducing of 15 extracts was evaluated using the fluorescence recovery after photobleaching (FRAP) method and the results of the experiment were given as $\mathrm{mM} \mathrm{Fe}{ }^{2+} / \mathrm{mg}$ extract ${ }^{[21]}$. Cupric reducing antioxidant 
properties of 15 extracts was carried out according to the method of Apak et al. ${ }^{[22]}$ and, the data obtained was presented as $\mathrm{mM}$ Trolox/mg extract.

\section{In vitro antiurease activity:}

Antiurease activities of the 15 extracts of A. vermicularis were evaluated using the indophenol method with some modifications and the results were expressed as percent enzyme inhibition ${ }^{[23]}$.

\section{In vitro antiinflammatory activity:}

The non-toxic concentrations of the extracts were determined using a WST-1 assay kit (Roche Applied Sciences) according to the manufacturer's instructions. Raw 264.7 cells ( 22.500 cells/well) in $10 \%$ fetal bovine serum-Dulbecco's modified Eagle media were seeded into 96-well plates. The cells were co-incubated with the extracts and $1 \mu \mathrm{g} / \mathrm{ml}$ lipopolysaccharide (LPS) for $24 \mathrm{~h}$ at $37^{\circ}$. The nitrite accumulated in the culture medium was measured by Griess assay. The nitrite concentration in the samples was calculated from the standard curve of sodium nitrite ${ }^{[24]}$.

\section{Analysis of phenolic compounds:}

The active phenolic compounds in $\mathrm{MC}$ were identified by HPLC-DAD and liquid chromatography quadrupole time-of-flight mass spectrometry (LC-QTOF/MS) ${ }^{[25]}$. MS/MS analysis of phenolic compounds was carried out in negative mode using electrospray ionization. The HPLC gradient elution was performed using water with trifluoroacetic acid (TFA, $0.1 \%$; phase A) and acetonitrile with TFA $(0.1 \%$; phase B) as mobile phase and the solvent gradient changed according to the following conditions: $0 \mathrm{~min}, 5 \% \mathrm{~B} ; 1 \mathrm{~min}, 5 \%$ B; $20 \mathrm{~min}, 30 \% \mathrm{~B}$; $25 \mathrm{~min}, 60 \% \mathrm{~B}$; $28 \mathrm{~min}, 60 \% \mathrm{~B}$; 33 min, $95 \%$ B; 35 min, $95 \%$ B; 40 min, $5 \%$ B. All the extracts and standards were prepared by dissolving in methanol/water $(2: 1 ; v / v)$ solution, then the obtained solutions were filtered through $0.45 \mu \mathrm{m}$ syringe filter and the mobile phases were degassed before injection on to HPLC.

\section{Statistical analysis:}

The results of the antioxidant and antiurease experiments were analysed by the GraphPad Prism 5 program. The data obtained from antiinflammatory activity were analysed by PASW Statistics.

\section{RESULTS AND DISCUSSION}

The total phenolic values and percent yield of the 15 extracts were analysed and results shown in Table 1. SEA (0.044 $\mathrm{mg}$ GAE/mg), UC (0.043 mg GAE/mg), SC (0.037 mg GAE/mg) and $\mathrm{MC}$ (0.036 mg GAE/mg) extracts have shown higher content of phenolic compounds than other extracts. The $n$-hexane extracts showed lower total phenolic contents in all three extraction methods. As a result, it was found that the total phenolic contents in the SEA and UC extracts were very close to each other and higher than the other extracts. When the percent yields of 15 different extracts were compared, Soxhlet method (excluding UEW extract) exhibited highest recovery over other extraction methods.

The antioxidant properties of these 15 extracts of A. vermicularis are shown in Table 2 . The SEW $\left(\mathrm{IC}_{50} 0.109 \mathrm{mg} / \mathrm{ml}\right), \mathrm{UEW}\left(\mathrm{IC}_{50} 0.172 \mathrm{mg} / \mathrm{ml}\right)$ and MEA $\left(\mathrm{IC}_{50} 0.251 \mathrm{mg} / \mathrm{ml}\right)$ extracts exhibited stronger DPPH free radical scavenging properties than other extracts. The $n$-hexane extracts obtained using all 3 extraction methods showed lower DPPH free radical scavenging activity than all the other extracts. BHA and ascorbic acid were used as positive controls. According to the results of the ABTS cation radical scavenging, the MEW (34.983 mM Trolox/mg), MC (30.818 mM Trolox/mg), SC (27.169 mM Trolox/mg) and UC (20.494 mM Trolox/mg) extracts showed the strongest ABTS cation radical scavenging activity. The $n$-hexane extracts from all extraction methods showed lowest ABTS cation radical scavenging activity. Chloroform extract showed highest activity over all other extraction methods except by the maceration method.

TABLE 1: PERCENT EXTRACT YIELD AND TOTAL PHENOLIC CONTENTS OF A. VERMICULARIS

\begin{tabular}{|c|c|c|c|c|c|c|}
\hline \multirow[b]{2}{*}{ Samples } & \multicolumn{3}{|c|}{ Total phenolic content (mgGAE/mg) } & \multicolumn{3}{|c|}{ Extract yield (\%) } \\
\hline & Ultrasonic bath & Maceration & Soxhlet & Ultrasonic bath & Maceration & Soxhlet \\
\hline$n$-Hexane & $0.017 \pm 0.01$ & $0.018 \pm 0.01$ & $0.016 \pm 0.01$ & 0.44 & 1.18 & 1.39 \\
\hline Chloroform & $0.043 \pm 0.09$ & $0.036 \pm 0.02$ & $0.037 \pm 0.05$ & 0.89 & 0.82 & 0.95 \\
\hline Ethyl acetate & $0.023 \pm 0.02$ & $0.027 \pm 0.03$ & $0.044 \pm 0.02$ & 0.10 & 0.12 & 0.31 \\
\hline Ethanol & $0.02 \pm 0.01$ & $0.025 \pm 0.01$ & $0.028 \pm 0.01$ & 0.87 & 3.67 & 5.77 \\
\hline Ethanol-water $(50: 50, v / v)$ & $0.029 \pm 0.02$ & $0.024 \pm 0.10$ & $0.032 \pm 0.01$ & 5.44 & 4.26 & 5.25 \\
\hline
\end{tabular}

Values are mean of triplicate determination $(n=3) \pm$ standard deviation; GAE- gallic acid equivalents 
TABLE 2: EFFECTS OF EXTRACTING SOLVENTS/METHODS ON THE ANTIOXIDANT ACTIVITY OF A. VERMICULARIS EXTRACTS

\begin{tabular}{|c|c|c|c|c|c|c|c|c|c|c|c|c|}
\hline \multirow{2}{*}{ Samples } & \multicolumn{3}{|c|}{$\mathrm{DPPH} \cdot\left(\mathrm{IC}{ }_{50} \mathrm{mg} / \mathrm{ml}\right)$} & \multicolumn{3}{|c|}{ ABTS (mM Trolox/mg) } & \multicolumn{3}{|c|}{ FRAP assay $\left(\mathrm{mM} \mathrm{Fe}^{2+} / \mathrm{mg}\right)$} & \multicolumn{3}{|c|}{$\begin{array}{c}\text { CUPRAC assay (mM } \\
\text { Trolox/mg) }\end{array}$} \\
\hline & $\begin{array}{l}\text { Ultrasonic } \\
\text { bath }\end{array}$ & $\begin{array}{l}\text { Mace- } \\
\text { ration }\end{array}$ & Soxhlet & $\begin{array}{l}\text { Ultrasonic } \\
\text { bath }\end{array}$ & $\begin{array}{l}\text { Mace- } \\
\text { ration }\end{array}$ & Soxhlet & $\begin{array}{l}\text { Ultrasonic } \\
\text { bath }\end{array}$ & $\begin{array}{l}\text { Mace } \\
\text { ration }\end{array}$ & Soxhlet & $\begin{array}{c}\text { Ultrasonic } \\
\text { bath }\end{array}$ & $\begin{array}{l}\text { Mace- } \\
\text { ration }\end{array}$ & Soxhlet \\
\hline$n$-Hexane & $\begin{array}{l}3.693 \\
\pm 0.79^{\mathrm{a}}\end{array}$ & $\begin{array}{l}0.918 \\
\pm 0.03^{\mathrm{a}}\end{array}$ & $\begin{array}{c}1.751 \\
\pm 0.21^{\mathrm{a}}\end{array}$ & $\begin{array}{l}5.616 \\
\pm 0.24^{\mathrm{a}}\end{array}$ & $\begin{array}{l}2.609 \\
\pm 0.20^{\mathrm{a}}\end{array}$ & $\begin{array}{l}9.295 \\
\pm 0.46^{\mathrm{a}}\end{array}$ & $\begin{array}{l}4.221 \\
\pm 0.07^{\mathrm{a}}\end{array}$ & $\begin{array}{l}3.920 \\
\pm 0.12^{\mathrm{a}}\end{array}$ & $\begin{array}{l}6.216 \\
\pm 0.11^{\mathrm{a}}\end{array}$ & $\begin{array}{l}0.820 \\
\pm 0.03^{\mathrm{a}}\end{array}$ & $\begin{array}{l}1.023 \\
\pm 0.04^{\mathrm{a}}\end{array}$ & $\begin{array}{l}0.721 \\
\pm 0.02^{\mathrm{a}}\end{array}$ \\
\hline Chloroform & $\begin{array}{l}0.539 \\
\pm 0.04^{\mathrm{b}}\end{array}$ & $\begin{array}{l}0.275 \\
\pm 0.04^{b}\end{array}$ & $\begin{array}{l}0.231 \\
\pm 0.01^{\mathrm{b}}\end{array}$ & $\begin{array}{l}20.494 \\
\pm 1.99^{b}\end{array}$ & $\begin{array}{c}30.818 \\
\pm 0.2^{b}\end{array}$ & $\begin{array}{l}27.169 \\
\pm 2.13^{\mathrm{b}}\end{array}$ & $\begin{array}{l}9.202 \\
\pm 0.31^{\mathrm{b}}\end{array}$ & $\begin{array}{l}11.898 \\
\pm 0.36^{\mathrm{b}}\end{array}$ & $\begin{array}{l}13.954 \\
\pm 0.57^{\mathrm{b}}\end{array}$ & $\begin{array}{l}2.495 \\
\pm 0.13^{b}\end{array}$ & $\begin{array}{l}3.658 \\
\pm 0.03^{\mathrm{b}}\end{array}$ & $\begin{array}{l}4.023 \\
\pm 0.14^{\mathrm{b}}\end{array}$ \\
\hline $\begin{array}{l}\text { Ethyl } \\
\text { acetate }\end{array}$ & $\begin{array}{l}0.578 \\
\pm 0.07 c\end{array}$ & $\begin{array}{l}0.251 \\
\pm 0.02^{c}\end{array}$ & $\begin{array}{l}0.131 \\
\pm 0.01^{c}\end{array}$ & $\begin{array}{l}9.364 \\
\pm 0.63^{c}\end{array}$ & $\begin{array}{l}7.500 \\
\pm 0.76^{c}\end{array}$ & $\begin{array}{l}22.390 \\
\pm 0.97 \mathrm{c}\end{array}$ & $\begin{array}{l}6.293 \\
\pm 0.05^{c}\end{array}$ & $\begin{array}{l}6.680 \\
\pm 0.12^{c}\end{array}$ & $\begin{array}{l}13.488 \\
\pm 0.14^{c}\end{array}$ & $\begin{array}{l}1.259 \\
\pm 0.02^{c}\end{array}$ & $\begin{array}{l}0.955 \\
\pm 0.01^{c}\end{array}$ & $\begin{array}{l}1.839 \\
\pm 0.01^{c}\end{array}$ \\
\hline Ethanol & $\begin{array}{l}0.458 \\
\pm 0.13^{d}\end{array}$ & $\begin{array}{l}0.273 \\
\pm 0.03^{d}\end{array}$ & $\begin{array}{l}0.220 \\
\pm 0.02^{d}\end{array}$ & $\begin{array}{l}18.421 \\
\pm 1.09^{d}\end{array}$ & $\begin{array}{l}17.305 \\
\pm 0.6^{\mathrm{d}}\end{array}$ & $\begin{array}{l}23.353 \\
\pm 1.70^{\mathrm{d}}\end{array}$ & $\begin{aligned} & 4.898 \\
\pm & 0.07^{\mathrm{d}, \mathrm{a}, \mathrm{c}}\end{aligned}$ & $\begin{array}{c}6.171 \\
\pm 0.17^{\mathrm{d}, \mathrm{c}}\end{array}$ & $\begin{array}{l}6.147 \\
\pm 0.08^{d}\end{array}$ & $\begin{array}{l}1.497 \\
\pm 0.03^{\mathrm{d}}\end{array}$ & $\begin{array}{l}1.728 \\
\pm 0.07^{d}\end{array}$ & $\begin{array}{l}2.035 \\
\pm 0.07^{d}\end{array}$ \\
\hline $\begin{array}{l}\text { Ethanol- } \\
\text { water } \\
(50: 50, \\
v / v)\end{array}$ & $\begin{array}{l}0.172 \\
\pm 0.01^{\mathrm{e}}\end{array}$ & $\begin{array}{l}0.326 \\
\pm 0.066^{\mathrm{e}}\end{array}$ & $\begin{array}{c}0.109 \\
\pm 0.01^{\mathrm{e}}\end{array}$ & $\begin{array}{l}14.971 \\
\pm 0.96\end{array}$ & $\begin{array}{c}34.983 \\
\pm 1.3^{\mathrm{e}}\end{array}$ & $\begin{array}{l}20.650 \\
\pm 1.51^{\mathrm{e}}\end{array}$ & $\begin{array}{c}7.293 \\
\pm 0.1^{\mathrm{e}, \mathrm{b}, \mathrm{c}}\end{array}$ & $\begin{array}{c}9.998 \\
\pm 0.11^{\mathrm{e}, \mathrm{b}}\end{array}$ & $\begin{array}{l}9.407 \\
\pm 0.13^{\mathrm{e}}\end{array}$ & $\begin{array}{c}1.882 \\
\pm 0.02^{\mathrm{e}}\end{array}$ & $\begin{array}{l}1.392 \\
\pm 0.01 \mathrm{e}\end{array}$ & $\begin{array}{c}1.958 \\
\pm 0.01^{\mathrm{e}}\end{array}$ \\
\hline $\mathrm{BHA}$ & & $06 \pm 0$ & & & $63 \pm 0.01$ & & & $\begin{array}{l}16.91 \\
\pm 0.02^{f}\end{array}$ & & & & \\
\hline
\end{tabular}

Ascorbic

acid

$0.004 \pm 0.90^{g, f}$

$5.70 \pm 0.02^{f}$

Values are mean of triplicate determination $(n=3) \pm$ standard deviation; means with different superscripts ${ }^{(\mathrm{a}-\mathrm{f})}$ are significantly different, $\mathrm{p}<0.05$

The chloroform extracts obtained from three extraction methods exhibited the highest ferric reducing activity. The SC and SEA showed similar values to each other in ferric reducing activity. The $\mathrm{UH}$ and $\mathrm{MH}$ exhibited lower FRAP activity than other extracts. As a result, Soxhlet is the most suitable method to extract with most powerful ferric reducing activity.

When the results of the CUPRAC assay were examined, chloroform extracts obtained from three extraction methods showed the strongest cupric reducing antioxidant activity (Table 2 ). The UH and SH extracts had the lowest cupric reducing antioxidant activity. Soxhlet method of extraction is the most suitable method to get extracts with most powerful cupric reducing antioxidant activity.

The antioxidant activity of ethanol (50\%) and water extracts from $A$. vermicularis leaves and stems were reported earlier and the phenolic contents and antioxidant activity of extracts prepared using maceration method were analysed using FCR, FRAP and DPPH assay $^{[26]}$. The ethanol (50\%) extracts from plant leaves and stems exhibited total phenolic contents (24.7 $\pm 0.12 \mathrm{mg} \mathrm{GAE} / \mathrm{mg})$, FRAP (13.0 $\pm 0.1 \mathrm{mM} \mathrm{FeSO}_{4} /$ $\mathrm{mg}$ ) and DPPH radical scavenging activity (13.1\%) than water extract (total phenolic contents: $19.3 \pm 0.06 \mathrm{mg}$ GAE/g extract; FRAP: $6.9 \pm 0.04 \quad \mathrm{mM} \quad \mathrm{FeSO}_{4} / \mathrm{mg}$ extract; DPPH: $6.7 \%$ ). In contrast to the above study, the total phenolic contents and antioxidant activity of 15 different extracts obtained from plant's aerial parts were examined and the results obtained from the total phenolic contents were compared with the earlier reports, it was found that MEW extracts of aerial parts contained very close total phenolic compounds and exhibited stronger DPPH scavenging activity than MEW extract from leaves and stems. In addition, MEW extract from aerial parts showed lower ferric reducing activity than MEW extract from leaves and stems.

In another study by Gharibi et al, antioxidant activities of methanol ( $80 \%$ ) extracts of $A$. vermicularis leaves were screened by $\beta$-carotene-linoleic acid, DPPH, reducing power assays. The methanol extract exhibited moderate total phenolic (30.07 mg tannic acid/g), flavonoid contents (49.16 mg quercetin/g) and DPPH $\left(\mathrm{IC}_{50} 309.74 \mu \mathrm{g} / \mathrm{ml}\right), \beta$-carotene-linoleic acid (80\%), and reducing power (Abs $700 \mathrm{~nm}$ : 0.946) activity ${ }^{[27]}$. Contrary to the above study, it was found that the amount of total phenolic contents contained in the SE was very close to that of the methanol extract of leaves. And MEW extract showed close DPPH'scavenging activity to methanol extract from leaves.

In the present study, all the three assays showed that the UC, MC and SC extracts had strong ABTS, CUPRAC and FRAP activity. In addition, the chloroform extracts obtained from 3 extraction technical exhibited higher total phenolic content values than other extracts. Consequently, strong antioxidant activity recorded in chloroform extracts could be due to the high phenolic compounds. 
Correlation coefficients between antioxidant properties and phenolic compounds in extracts, which showed the highest antioxidant activities, are given in Table 3. According to the results a strong correlation was observed between total phenolic contents with FRAP activity (MEW, SC, UC, MC extracts), ABTS radical cation scavenging activity (SC and MC extracts), CUPRAC activity (SC, UC and MC extracts) and DPPH radical scavenging properties (MEA, SEW and UEW extracts). The data obtained from correlation coefficients and regression analysis revealed that phenolic compounds were responsible for the antioxidant activity in $A$. vermicularis extracts. Some studies on Achillea species have shown a significant relationship between phenolic compounds and antioxidant properties ${ }^{[28-31]}$. The linear relationship between the antioxidant activity and the total phenolic compounds in present study supports the literature.

The results for the assessment of urease inhibitory activity of $A$. vermicularis different extracts $(12.5 \mu \mathrm{g} / \mathrm{ml})$ obtained through 3 extraction techniques were shown in Table 4. The UEA (35.825 \%), SEW (32.945\%), MEW (31.985\%), MC (31.247\%) and UEW (31.201\%) extracts exhibited stronger antiurease activity than other extracts. In this study, thiourea was used as a positive control and all extracts showed lower antiurease activity than the positive control (78.54\%). In the present study, UEA was the most suitable solvent and method to get the strongest antiurease activity.

In the study, there is a strong correlation between total phenolic contents and antiurease activity of UEA $\quad\left(\mathrm{Y}=0.1312+125200 \mathrm{x}, \quad r^{2}=0.9998, \quad \mathrm{p}<0.05\right)$, SEW $\quad\left(\mathrm{Y}=0.3286+82590 \mathrm{x}, \quad r^{2}=0.9999, \quad \mathrm{p}<0.05\right)$, MEW $\left(\mathrm{Y}=1.381+105500 \mathrm{x}, r^{2}=0.9992, \mathrm{p}<0.05\right), \mathrm{MC}$ $\left(\mathrm{Y}=0.8765+63030 \mathrm{x}, r^{2}=0.9988, \mathrm{p}<0.05\right)$ and $\mathrm{UEW}$ $\left(\mathrm{Y}=0.6623+83460 \mathrm{x}, r^{2}=0.9990, \mathrm{p}<0.05\right)$ extracts of A. vermicularis.

However there are many reports in the literature about the antiurease properties of $A$. millefolium and A. lycaonica, but there is no information on other Achillea species $^{[23,32]}$. For this reason, the antiurease

TABLE 3: CORRELATION COEFFICIENTS BETWEEN ANTIOXIDANT ACTIVITY AND PHENOLIC COMPOUNDS

\begin{tabular}{|c|c|c|c|c|c|c|c|}
\hline $\begin{array}{l}\text { Chemical } \\
\text { parameters }\end{array}$ & $\begin{array}{c}\text { Maceration } \\
\text { ethanol-water } \\
(50: 50, v / v)\end{array}$ & $\begin{array}{l}\text { Maceration } \\
\text { ethyl acetate }\end{array}$ & $\begin{array}{l}\text { Soxhlet } \\
\text { chloroform }\end{array}$ & $\begin{array}{l}\text { Ultrasonic } \\
\text { bath- } \\
\text { chloroform }\end{array}$ & $\begin{array}{c}\text { Ultrasonic } \\
\text { bath ethanol- } \\
\text { water } \\
(50: 50, v / v)\end{array}$ & $\begin{array}{c}\text { Soxhlet- } \\
\text { ethanol- } \\
\text { water } \\
(50: 50, v / v) \\
\end{array}$ & $\begin{array}{l}\text { Maceration } \\
\text { chloroform }\end{array}$ \\
\hline DPPH & - & $\begin{array}{c}Y=0.889+7171 x \\
r^{2}=0.9563\end{array}$ & - & - & $\begin{array}{c}Y=2.984+ \\
9428 x \\
r^{2}=0.9848\end{array}$ & $\begin{array}{l}Y=2.295 \\
+13720 x \\
r^{2}=0.9996\end{array}$ & - \\
\hline ABTS & $\begin{array}{c}Y=0.4850- \\
1458 x \\
r^{2}=0.5204\end{array}$ & - & $\begin{array}{c}Y=0.09070- \\
760.2 x \\
r^{2}=0.9997\end{array}$ & $\begin{array}{c}Y=0.3591 \\
-498.2 x \\
r^{2}=0.4992\end{array}$ & - & - & $\begin{array}{c}\mathrm{Y}=0.005167+855.01 \mathrm{x} \\
r^{2}=0.9999\end{array}$ \\
\hline FRAP & $\begin{array}{c}Y=0.333+ \\
24.61 x \\
r^{2}=0.9950\end{array}$ & - & $\begin{array}{c}Y=0.03572- \\
378.9 x \\
r^{2}=0.9999\end{array}$ & $\begin{array}{c}Y=0.06561+ \\
203.8 x \\
r^{2}=0.9965\end{array}$ & - & - & $\begin{array}{c}Y=0.1373+652.2 x \\
r^{2}=0.9986\end{array}$ \\
\hline CUPRAC & - & - & $\begin{array}{c}Y=0.01003- \\
106.4 x \\
r^{2}=0.9999\end{array}$ & $\begin{array}{c}Y=0.054+ \\
55.02 x \\
r^{2}=0.9997\end{array}$ & - & - & $\begin{array}{c}Y=0.01456+98.25 x \\
r^{2}=0.9994\end{array}$ \\
\hline
\end{tabular}

Statistically significant at $\mathrm{p}<0.05$; the correlation coefficients and regression analysis were not calculated because they showed low activity

TABLE 4: UREASE INHIBITORY ACTIVITY OF DIFFERENT EXTRACTS FROM A.VERMICULARIS

\begin{tabular}{lccc}
\hline \multirow{2}{*}{ Samples } & \multicolumn{3}{c}{ Urease inhibition (\%) $(12.5 \mu \mathrm{g} / \mathrm{ml})$} \\
\cline { 2 - 4 } & Ultrasonic bath & Maceration & \multicolumn{1}{c}{ Soxhlet } \\
\hline$n$-Hexane & $23.873 \pm 0.50$ & $25.652 \pm 1.34$ & $18.080 \pm 1.92$ \\
Chloroform & $30.575 \pm 0.49$ & $31.247 \pm 0.54$ & $26.851 \pm 0.62$ \\
Ethyl acetate & $35.825 \pm 2.59$ & $21.659 \pm 0.57$ & $19.442 \pm 1.01$ \\
Ethanol & $25.354 \pm 0.56$ & $26.761 \pm 1.38$ & $30.804 \pm 0.64$ \\
Ethanol-water $(50: 50, v / v)$ & $31.201 \pm 2.37$ & $31.985 \pm 2.29$ & $32.945 \pm 2.47$ \\
Thiourea & & $78.54 \pm 0.60$ & \\
\hline
\end{tabular}

Values are mean of triplicate determination $(n=3) \pm$ standard deviation 
properties of 15 extracts from $A$. vermicularis were investigated for the first time and as a result, the ultrasonic bath method exhibited higher activity than other extraction methods.

Free radicals provoke inflammatory processes. For this reason, the use of antioxidants can attenuate inflammation. Therefore, in this study, antiinflammatory activities of chloroform extracts obtained by three extraction methods and showed strong antioxidant activity as shown in fig. 1 and 2 .
The non-toxic concentrations of the extracts on Raw 264.7 macrophages were determined by WST-1 assay (fig. 1). The cells were treated with the indicated concentrations of extracts with LPS $(1 \mu \mathrm{g} / \mathrm{ml})$, and incubated at $37^{\circ}$ for $24 \mathrm{~h}$. MC was applied to cells at $1.56,3.12,6.25$ and $12.5 \mu \mathrm{g} / \mathrm{ml}$ concentrations. The viability of the cells was not significantly affected. On the other hand, chloroform extracts (SC and UC) were applied at $3.13,6.25,12.5$ and $25 \mu \mathrm{g} / \mathrm{ml}$ concentrations. When SC and UC extracts were applied
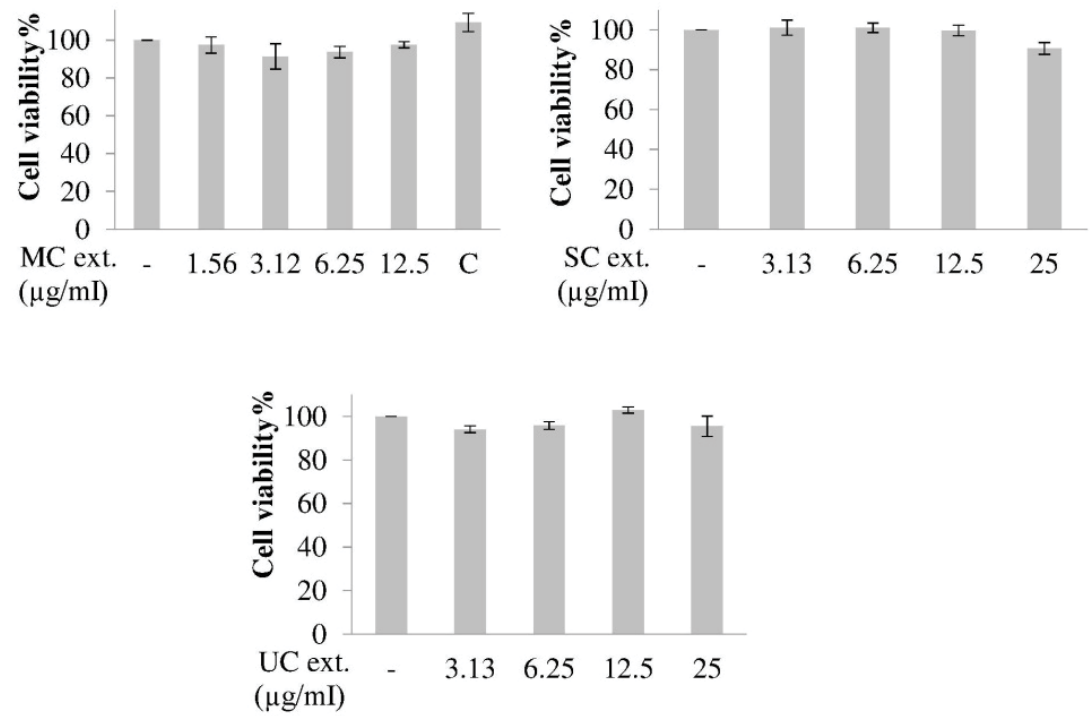

Fig. 1: Effect of $A$. vermicularis extracts on the viability of Raw 264.7 macrophages

Maceration chloroform (MC), Soxhlet chloroform (SC), and ultrasonic bath chloroform (UC). Cell viability was determined by WST-1 assay. Cells were treated with the indicated concentrations of extracts with LPS (1 mg/ml) for $24 \mathrm{~h}$. C: L-NIL applied at $10 \mathrm{M}$ concentration. Error bars represent the mean \pm SEM for three experiments. Values of * $p<0.05$ were considered statistically significant

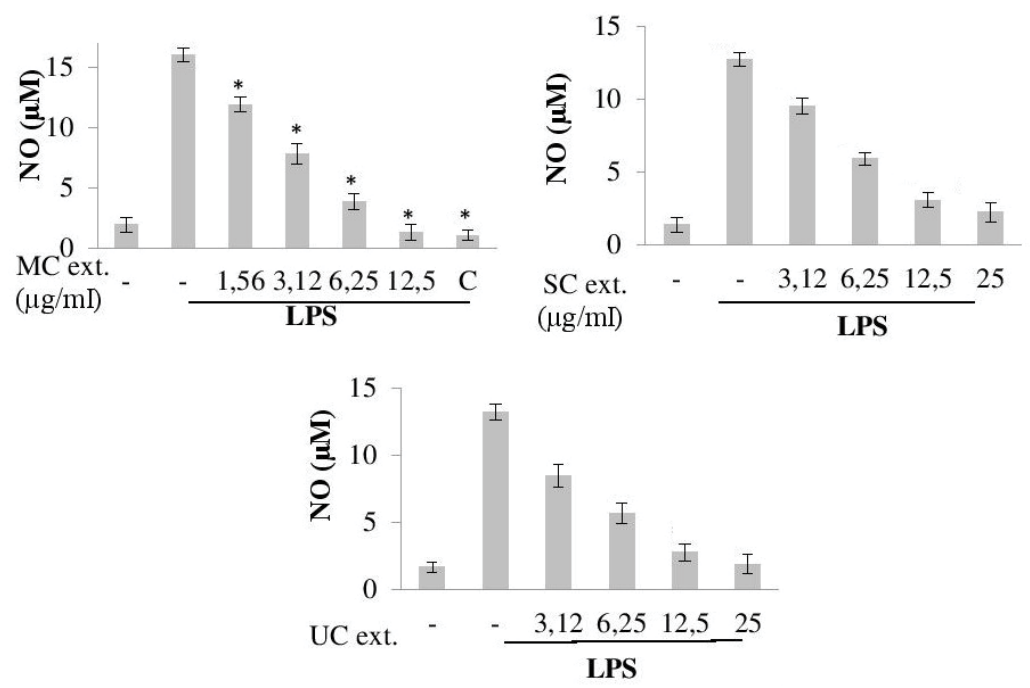

Fig. 2: Effect of $A$. vermicularis extracts on the NO productions of LPS-induced Raw 264.7 macrophages

Maceration chloroform (MC), Soxhlet chloroform (SC), and ultrasonic bath chloroform (UC). NO concentrations were determined by Griess Assay. Cells were co-incubated with the indicated concentrations of extracts and LPS (1 mg/ml) for $24 \mathrm{~h}$. C: L-NIL applied at $10 \mu \mathrm{M}$ concentration. Error bars represent the mean \pm SEM. Values of ${ }^{*} p<0.05$ vs. LPS-treated control group were considered statistically significant 
to cells at $25 \mu \mathrm{g} / \mathrm{ml}$ concentrations, the cell viabilities were $90.61 \pm 2.95$ and $95.55 \pm 4.70 \%$, respectively. The cytotoxic effect of L-N6-(1-iminoethyl) lysine (L-NIL) at $10 \mu \mathrm{M}$ concentration was evaluated on Raw 264.7 macrophages and this concentration did not significantly decrease the viability of Raw 264.7 cells.

Raw 264.7 macrophage cells were incubated with the indicated concentrations of the extracts and induced with LPS $(1 \mu \mathrm{g} / \mathrm{ml})$ for $24 \mathrm{~h}$. As shown in fig. 2. LPS treatment of cells significantly increased NO levels. All extracts exerted significant inhibitory activity on LPSinduced NO production of Raw 264.7 macrophages. The most active extract was $\mathrm{MC}$, which inhibited $25.92,51.42,75.89,92.15 \%$ of NO productions when the cells were treated with $1.56,3.12,6.25$, $12.5 \mu \mathrm{g} / \mathrm{ml}$ concentrations. SC extract applied to cells at $3.12,6.25,12.5$ and $25 \mu \mathrm{g} / \mathrm{ml}$ concentrations and inhibited the NO production of cells by 24.97, 53.57, 75.93 and $82.36 \%$, respectively. UC extract applied at the same concentrations inhibited 35.72, 57.11, 78.93, $85.61 \%$ of NO production compared with only LPStreated control group. As shown in fig. 2, L-NIL at $10 \mu \mathrm{M}$ inhibited $93.60 \%$ of NO production of the LPSinduced Raw 264.7 macrophages.

Antinociceptive and antiinflammatory activities of ethanol and water extracts from A. vermicularis have been previously studied using $p$-benzoquinoneinduced writhing test and carrageenan-induced hind paw edema test ${ }^{[33]}$. According to the study, the ethanol extract of plant displayed significant antinociceptive and antiinflammatory activity at $500 \mathrm{mg} / \mathrm{kg}$ oral dose, without inducing any apparent acute toxicity as well as gastric damage. Contrary to this study, antiinflammatory and antioxidant activities of chloroform extracts were investigated in vitro. And it was found that the MC extract showed the strongest antioxidant and antiinflammatory activity.

Phenolic compounds in MC extract were analysed as this extract showed strongest antioxidant and antiinflammatory activity by HPLC-DAD and ESI-QTOF LC/MS. The phenolic compounds were identified as chlorogenic acid, caffeic acid, rutin, dicaffeoylquinic acid, naringenin, quercetagetin 3,6-dimethyl ether, and 8-hydroxy-salvigenin (Table 5). Three new sesquiterpene hemiacetals (achilleanone, vermiculone and vermicularone) and known compounds ( $\beta$-amyrin, oleonolic acid and $\beta$-sitosterol) from $A$. vermicularis have previously been isolated $d^{[34]}$. Contrary to the above study, the effects of extraction technical and solvents on biological properties were examined in the present study. Then, the phenolic compounds in chloroform extract that showed strong antioxidant and antiinflammatory activity were analysed by HPLCDAD and LC-QTOF/MS. As a result, chlorogenic acid, rutin, dicaffeoylquinic acid, naringenin, quercetagetin 3,6-dimethyl ether, and 8-hydroxy-salvigenin compounds were analysed for the first time in A. vermicularis.

In this study, 3 extraction methods and 5 solvents were employed in order to obtain the biologically active components of $A$. vermicularis. It was found that, in the three extraction techniques, the type of solvent used significantly influence the extraction yield and available amount of phenolics. In the three extraction methods, the highest extract yield percent and the amount of phenolics were obtained with ethanol, ethanol-water $(50: 50, v / v)$ and chloroform, ethyl acetate solvents, respectively. Also, among the methods of extraction, the Soxhlet method is the most suitable method for obtaining the highest extract yield and amount of phenolics. The DPPH· method is highly suitable for evaluating the activity of polar compounds and in parallel with this information it was found that SEW extract, which had rich polar compounds showed the strongest DPPH radical scavenging activity. The ABTS.+, FRAP and CUPRAC methods are highly suitable for evaluating the activity of lipophilic and hydrophilic compounds. The chloroform extracts

TABLE 5: THE MAIN PHENOLIC COMPOUNDS IN A. VERMICULARIS CHLOROFORM EXTRACT IDENTIFIED BY MS/MS

\begin{tabular}{lcccc}
\hline Components & $\begin{array}{c}\text { PDA } R_{\mathrm{t}} \\
(\mathrm{min})\end{array}$ & $\begin{array}{c}\lambda \max (\mathrm{nm}) \\
\left(\mathrm{MeOH}: \mathrm{H}_{2} \mathbf{O}\right)\end{array}$ & $\begin{array}{c}{[\mathrm{M}-\mathrm{H}]^{-}} \\
\mathbf{m} / \mathbf{z}\end{array}$ & $\begin{array}{c}\mathrm{MS} / \mathrm{MS} \mathrm{CE}: 10-30 \mathrm{eV} \\
\mathbf{m} / \mathbf{z} \text { fragment }\end{array}$ \\
\hline Chlorogenic acid & 11.23 & $218,235,325$ & 353.0878 & 191,179 \\
Caffeic acid & 12.53 & $217,234,323$ & 179.0329 & 135 \\
Rutin & 16.43 & 255,353 & 609.2080 & 301 \\
Dicaffeoylquinic acid & 18.19 & $216,234,327$ & 515.1277 & $353,191,179$ \\
Naringenin & 25.78 & 267,337 & 270.8747 & 179,144 \\
Quercetagetin3,6-dimethyl ether & 24,67 & 258,350 & 345.0565 & $330,315,287$ \\
8-hydroxy-salvigenin & 29.32 & 271,336 & 344.0872 & $329,314,286,271,242,186$ \\
\hline
\end{tabular}


obtained from three extraction methods (especially Soxhlet method had the highest FRAP and CUPRAC activity) generally showed stronger antioxidant activity than other extracts. Also, these extracts exhibited strong antiinflammatory activity. In addition, it was found that UEA was the most suitable extract with the strongest antiurease activity. In this study, it was determined that extraction methods and types of solvents in plant biological activity were very effective. As a result, it was found that the most suitable extraction method/solvent for antioxidant and antiinflammatory activity was maceration/chloroform. In addition, the compounds that could be responsible for biological activity were analysed by ESI-Q-TOF LC/MS. As a result, chlorogenic acid, rutin, dicaffeoylquinic acid, naringenin, quercetagetin 3,6-dimethyl ether, and 8- hydroxy-salvigenin compounds were analysed for the first time in A. vermicularis. Therefore, $\mathrm{MC}$ and UEA extracts of $A$. vermicularis could be used as natural source for antioxidants, antiinflammatory and antiurease agents for food and pharmaceutical industry.

\section{Conflict of interest:}

The authors state that they have no conflicts of interest.

\section{REFERENCES}

1. Saeidnia S, Gohari AR, Mokhber-Dezfuli N, Kiuchi F. A review on phytochemistry and medicinal properties of the genus Achillea. Daru 2011;19(3):73-86.

2. Ghantous A, Nasser N, Saab I, Darwiche N, Saliba NA. Structure-activity relationship of seco-tanapartholides isolated from Achillea falcata for inhibition of $\mathrm{HaCaT}$ cell growth. Eur J Med Chem 2009;44:3794-7.

3. Yong L, Zhang ML, Cong B, Wan SM, Dong M, Sauriol F, et al. Achillinin A, a cytotoxic guaianolide from the flower of Yarrow, Achillea millefolium. Biosci Biotechnol Biochem 2011;75(8):1554-6.

4. Skocibusic M, Bezic N, Dunkic V, Radonic A. Antibacterial activity of Achillea clavennae essential oil against respiratory tract pathogens. Fitoterapia 2004;75:733-6.

5. Tuberosoa CIG, Montorob P, Piacenteb S, Coronac G, Deianac M, Dessic MA, et al. Flavonoid characterization and antioxidant activity of hydroalcoholic extracts from Achillea ligustica All. J Pharm Biomed Anal 2009;50:440-8.

6. Khazneh E, Saltan G, Tekin M, Acıkara ÖB, Yeşiloğlu T, Özbilgin S. The importance of Achillea species and phenolic compounds in Achillea schıschkını Sosn. J Fac Pharm Ankara 2010;39(1):43-50.

7. Behçet L, Arık M. An ethnobotanical investigation in east Anatolia (Turkey). Turk J Nat Sci 2013;2(1):1-89.

8. Bulut G, Biçer M, Tuzlacı E. The folk medicinal plants of Yüksekova (Hakkari- Turkey). J Fac Pharm Istanbul 2016;46(2):15-124.

9. Polatoglu K, Karakoc ÖC, Gören N. Phytotoxic, DPPH· scavenging, insecticidal activities and essential oil composition of Achillea vermicularis, A. teretifolia and proposed chemotypes of $A$. biebersteinii (Asteraceae). Ind Crop Prod 2013;51:35-45.

10. Osboo RK, Miri R, Jassbi AR. Comparative study of the volatiles in the essential oils of Achillea wilhelmsii, A. vermicularis and A.eriophora by hydrodistillation and head space solid phase microextraction (HS-SPME) Gas Chromatography-Mass Spectroscopy (GC-MS) Analyses. J Essent Oil Bear P1 2015;18 (6):1433-40.

11. Amin M, Anwar F, Naz F, Mehmood T, Saari N. AntiHelicobacter pylori and urease inhibition activities of some traditional medicinal plants. Molecules 2013;18:2135-49.

12. Modolo LV, Souza AX, Horta LP, Araujo DP, Fa'tima A. An overview on the potential of natural products as ureases inhibitors: A review. J Adv Res 2015;6:35-44.

13. Wang YC. Medicinal plant activity on Helicobacter pylori related diseases. World J Gastroenterol 2014;20(30):1036882.

14. Sardin AER, Ver'onica A, Villar B, Gonz'alez Aguilar GA, Rosa LA. Flavonoids and their relation to human health. In: Rosa LA, Parrilla EA, Aguilar G, editors. Fruit and Vegetable Phytochemicals Chemistry, Nutritional Value, and Stabilit. Hoboken, New Jersey: Blackwell Publishing; 2010. p. 150-70.

15. Conforti F, Sosa S, Marrelli M, Menichini F, Statti GA, Uzunov $\mathrm{D}$, et al. In vivo antiinflammatory and in vitro antioxidant activities of Mediterranean dietary plants. J Ethnopharmacol 2008;116:144-51.

16. Lacueva CA, Remon AM, Llorach R, Sarda MU, Khan $\mathrm{N}$, Blanch GC, et al. Phenolic compounds: chemistry and occurrence in fruits and vegetables. In: Rosa LA, Parrilla EA, Aguilar G, editors. Fruit and Vegetable Phytochemicals Chemistry, Nutritional Value, and Stabilit. Hoboken, New Jersey: Blackwell Publishing; 2010. p. 170-90.

17. Nicolas JML, Carmona FG. Enzymatic and Nonenzymatic Degradation of Polyphenols. In: Rosa LA, Parrilla EA, Aguilar G, editors. Fruit and Vegetable Phytochemicals Chemistry, Nutritional Value, and Stabilit. Hoboken, New Jersey: Blackwell Publishing; 2010. p. 200-30.

18. Ozsoy N, Can A, Yanardağ R, Akev N. Antioxidant activity of Smilax excelsa L. leaf extracts. Food Chem 2008;110(3):571-83.

19. Wei F, Jinglou C, Yaling C, Yongfang L, Liming C, Lei P. Antioxidant, free radical scavenging, antiinflammatory and hepatoprotective potential of the extract from Parathelypteris nipponica (Franch.etSav.) Ching. J Ethnopharmacol 2010;130:521-8.

20. Re R, Pellegrıni N, Proteggente A, Pannala A, Yang M, Evans CR. Antioxidant activity applying an improved ABTS radical cation decolorization assay. Free Radic Biol Med 1999;26:1231-7.

21. Benzie IF, Strain JJ. The ferric reducing ability of plasma (FRAP) as a measure of "antioxidant power": the FRAP assay. Anal Biochem 1996;239(1):70-6.

22. Apak R, Güclü K, Ozyurek M, Karademir SE. Novel total antioxidant capacity index for dietary polyphenols and vitamins $\mathrm{C}$ and $\mathrm{E}$, using their cupric ion reducing capability in the presence of neocuproine: CUPRAC Method. J Agric Food Chem 2004;52(26):7970-81.

23. Ghous T, Akhtar K, Nasim FUH, Choudhry MA. Screening of selected medicinal plants for urease inhibitory activity. Biol Med 2010;2(4):64-9.

24. Balkan İA, İlter Akülke AZ, Bağatur Y, Telci D, Gören AC, 
Kırmızıbekmez H, et al. Sambulin A and B, non-glycosidic iridoids from Sambucus ebulus, exert significant in vitro anti-inflammatory activity in LPS-induced RAW 264.7 macrophages via inhibition of MAPKs's phosphorylation. J Ethnopharmacol 2017;206:347-52.

25. Halpine SM. An improved dye and lake pigment analysis method for high-performance liquid chromatographyy and diode-array detector. Stud Conserv 1996;41:76-94.

26. Molan AL, Faraj Ami, Mahdy AS. Antioxidant activity and phenolic content of some medicinal plants traditionally used in Northern Iraq. Phytopharmacology 2012;2(2):224-33.

27. Gharibi S, Tabatabaei BES, Saeidi G. Comparison of essential oil composition, flavonoid content and antioxidant activity in eight Achillea species. J Essent Oil Bear Pl 2015;18(6):382-94.

28. Konyalioglu S, Karamenderes C. Screening of total flavonoid, phenol contents and antioxidant capacities of Achillea L. species growing in Turkey. Acta Pharm Turcica 2004;46:163-70.

29. Bashi DS, Bazzaz BSF, Sahebkar A, Karimkhani MM, Ahmadi A. Investigation of optimal extraction, antioxidant, and antimicrobial activities of Achillea biebersteinii and A. wilhelmsii. Pharm Biol 2012;50:1168-76.

30. Baris D, Kizil M, Aytekin C, Kizil G, Yavuz M, Ceken B, Ertekin $\mathrm{S}$. The in vitro antimicrobial and antioxidant activity of ethanol extract of three Hypericum and three Achillea species from Turkey. Int J Food Prop 2011;14:339-55.

31. Giorgi A, Bombelli R, Luini A, Speranza G, Cosentino M, Lecchini S, et al. Antioxidant and cytoprotective properties of infusions from leaves and inflorescences of Achillea collina Becker ex Rchb. Phytother Res 2009;23:540-5.

32. Taskin T, Taşkın D, Rayaman E, Dikpınar T, Süzgeç-Selçuk $\mathrm{S}$, Arabac1 T. Characterization of the biological activity and phenolics in Achillea lycaonica. Anal Lett 2018;51(1):33-48.

33. Küpeli E, Orhan İ, Küsmenoğlu Ş, Yeşilada E, Evaluation of anti-inflammatory and antinociceptive activity of five Anatolian Achillea species. Turk J Pharm Sci 2007;4(2):89-99.

34. Ahmad VU, Faroo U, Hussain J, Abbası MA, Jassbi AR, Nawaz SA, et al. Three new sesquiterpene hemiacetals from Achillea vermicularis. Nat Prod Res 2005;19(6):551-9. 